\title{
THE RIGHT TO SUBSISTENCE MINIMUM AND ITS ROLE IN THE PROTECTION OF PEOPLE LIVING IN EXTREME POVERTY- THE POLISH EXPERIENCE
}

\begin{abstract}
Subsistence minimum guaranteed to each individual by the public authorities may be perceived as a human right under the constitutional law. That right becomes even more important when the ability to question social and economic rights is limited. That was the case in the Polish constitutional system, among others. Because of the restrictions on the ability to question ESC-rights, the Polish Constitutional Tribunal found "subsistence minimum" as a special type of constitutional value inferred from human dignity which is guaranteed to every person under the Constitution. While giving its judgment, the Polish Constitutional Tribunal made reference to the case law of the Federal Constitutional Court of Germany which inferred "The fundamental right to guarantee a subsistence minimum that is in line with human dignity" from the German Basic Law. That right is of special importance for individuals who live in extreme poverty.
\end{abstract}

\section{Keywords}

subsistence minimum - human dignity - extreme poverty - ESC rights - Constitution of Poland - Polish Constitutional Tribunal - Federal Constitutional Court of Germany

* PhD, Centre for Human Rights, Faculty of Law and Administration, University of Warsaw. ORCID: https:/ / orcid.org/0000-0002-9116-7679. This paper has been developed as part of the research project no. 2015/19/N/HS5/00005 financed by funds from the National Science Centre, Poland. 


\section{INTRODUCTION}

The issues relating to the economic-, social- and cultural rights which had been outside the mainstream of the human rights discourse for a long time, in the last few years have been becoming more and more topical. The justiciability of the economic-, social- and cultural rights (hereinafter ESCrights) in particular has become a very popular topic in that area ${ }^{1}$. One of the reasons is that the effective enforcement of ESC-rights, including in particular the right to food, water, housing, and health ${ }^{2}$, is of fundamental importance for people who live in extreme poverty, and international human rights law puts more and more emphasis on the need to protect those people ${ }^{3}$.

${ }^{1}$ See: M. Langford, (eds.), Social Rights Jurisprudence Emerging Trends in International and Comparative Law, Cambridge 2008; K. Wojtyczek (eds.) Social Rights as Fundamental Rights XIXth International Congress of Comparative Law, Eleven International Publishing, Hague, 2016; E. Riedel, G. Giacca, C. Golay (eds.) Economic, Social, and Cultural Rights in International Law Contemporary Issues and Challenges, Oxford 2012; S. Liebenberg, SocioEconomic Rights: Adjudication Under a Transformative Constitution, Juta 2010; D. Bilchitz, Poverty and Fundamental Rights. The Justification and Enforcement of Socio-Economic Rights, Oxford 2012; K.G. Young, The Minimum Core of Economic and Social Rights: A Concept in Search of Content, "Yale Journal of International Law" 2008, vol. 33, no 1, pp. 113-175.

${ }^{2}$ See for example: Bart F. W. Wernaart, The enforceability of the human right to adequate food: a comparative study, Wageningen Academic Publishers, 2013; C. Courtis, The Right to Food as a Justiciable Right: Challenges and Strategies, "Max Planck Yearbook of United Nations Law" 2007, vol. 11, p. 317-337, G.S. McGraw, Defining and Defending the Right to Water and its Minimum Core: Legal Construction and the Role of National Jurisprudence, “Loyola University Chicago International Law Review” 2011, vol. 8, no. 2, pp. 127-204 (2011); K. Young, J. Lemaitre, The Comparative Fortunes of the Right to Health: Two Tales of Justiciability in Colombia and South Africa, "Harvard Human Rights Journal" 2013, vol. 26, pp. 179-216.

3 See: UN Guiding Principles on Extreme Poverty and Human Rights (A/HRC/21/39). The above mentioned rights were listed among other rights whose enjoyment by persons living in poverty is particularly limited and obstructed, and in relation to which State policies are often inadequate or counterproductive (see: guiding principle no. 62). Concerning the human rights based approach to poverty reduction see: A. Sengupta, Human Rights and Extreme Poverty, "Economic \& Political Weekly" 2010, vol. XLV, no. 17, pp. 85-93; R. Kanbur, Attacking Poverty: What is the Value Added of a Human Rights Approach? [in:] A.K. Sengupta, S.P. Marks, B.A. Andreassen (eds.), Freedom from Poverty as a Human Right, vol. 3, Economic Perspectives, Paris, 2010, pp. 13-17; M. Nowak, A Human Rights 
As the enforcement of ESC-rights in the courts is still considered controversial, the legal science and constitutional courts' jurisprudential practice are also looking for other legal ways to ensure that the basic needs of people are met, especially in the case of people who live in extreme poverty. Reinterpretation of guarantees under civil- and political rights and freedoms is one of such ways, as it allows for extending them to cover the duties of public authorities relating to the fulfilment of basic human needs. The right to dignity, or the principle of dignity, which exists in many constitutional systems has particular potential in that area ${ }^{4}$. The importance of that right is best visible in the judicial decisions of the Federal Constitutional Court of Germany (ger. Bundesverfassungsgericht) to which refers also the Polish Constitutional Tribunal (pol. Trybunat Konstytucyjny).

The purpose of this paper is to analyze the manner in which, before the ongoing constitutional crisis in Poland which started in $2015^{5}$, the Polish Constitutional Tribunal (hereinafter: CT inferred the subsistence minimum guaranteed under Article 30 of the Polish Constitution as an inherent constitutional value. In the case of difficulties in questioning a breach of social rights, that value becomes a basic tool for human rights defenders who defend the rights of people living in extreme poverty. This paper also attempts to find an answer to the question regarding the direction to be followed by CT case law concerning those issues, and whether the constitutional crisis will have any impact on this. In this context I will refer to the two most important judgments of the Federal

Approach to Poverty, "Human Rights in Development Online" 2002, vol. 8, no. 1, pp. 15-35; S. Osmani, Poverty and Human Rights: Building on the Capability Approach, "Journal of Human Development" 2005, vol. 6, no. 2, pp. 205-219.

${ }^{4}$ See also Romanian example: E.S. Tanasescu, Human dignity and the circumstantial protection of social rights [in:] M. Zubik, (ed.) Human Rights in contemporary world essays in honour of Professor Leszek Garlicki, Warsaw 2016, pp. 306-315. See also: E. Daly, Dignity Rights: Courts, Constitutions, and the Worth of the Human Person, Philadelphia, 2012; D. Kretzmer, E. Klein (eds) The Concept of Human Dignity in Human Rights Discourse, Hague, 2002; H. Botha, Human Dignity in Comparative Perspective, "Stellenbosch Law Review" 2009, vol. 20, pp. 171-220; P. Sourlas, Human Dignity and the Constitution, "Jurisprudence - An International Journal of Legal and Political Thought" 2016, vol., issue 1, pp. 30-46.

${ }^{5}$ More about the constitutional and rule of law crisis in Poland in sub-chapter 5 of this paper. 
Constitutional Court of Germany which may be an inspiration for the Polish Constitutional Tribunal. Those two judgments shaped the way the right to subsistence minimum is understood under the German legal system.

\section{ESC-RIGHTS UNDER THE CONSTITUTION of THE REPUBLIC OF POLAND}

The importance of the minimum subsistence guaranteed under the Constitution as an inherent constitutional value becomes fully visible only if we compare it to the way the ESC-rights are guaranteed under the effective Constitution and the controversies relating to the possibility of enforcing those rights in court.

In order to give a brief description of how ESC-rights had been regulated in the 1997 Constitution of the Republic of Poland ${ }^{6}$, it needs to be noted first that the Polish Constitution contains one of the broadest catalogues of ESC-rights among the constitutions effective in Central and Eastern Europe ${ }^{7}$. However, as a matter of principle, the ESC-rights guaranteed under the Polish Constitution have been formulated as the "programmatic norms" which define the duties of the public authorities; only a few of those rights are rights that may be exercised by individuals 9 . This way of guaranteeing ESC-rights resulted in fears about a flood of

${ }^{6}$ The Constitution of the Republic of Poland of 2nd April 1997, published in Journal of Laws No. 78, item 483.

7 W. Sadurski, Prawo przed sądem. Studium sądownictwa konstytucyjnego w postkomunistycznych państwach Europy Środkowej i Wschodniej [Law in front of a court. The study of constitutional judiciary in post-communist countries of Central and Eastern Europe], Warsaw 2008, p. 246.

${ }^{8}$ See for example: Article 75.1 of the Constitution which reads: "Public authorities shall pursue policies conducive to satisfying the housing needs of citizens, in particular combating homelessness, promoting the development of low-income housing, and supporting activities aimed at acquisition of a home by each citizen", or Article 62.2 which reads as follows: "equal access to health care services, financed from public funds, shall be ensured by public authorities to citizens, irrespective of their material situation. The conditions for, and scope of, the provision of services shall be established by statute".

9 See for example: Article 68.1 "Everyone shall have the right to have his health protected" or Article 67.2 which reads as follows "A citizen who is involuntarily without 
litigation in relation to social benefits which were very visible in the process of drafting the Polish Constitution in the 90s. The founding fathers of the Polish Constitution were afraid that the Polish economy transforming from a centrally planned to a free market would not be able to bear the burden of guaranteeing social rights to individuals. In the constitutional debate there were strong voices saying that social rights should be excluded from the Constitution.

An analysis of the jurisprudence of the Constitutional Tribunal, leads to the conclusion that the above mentioned division and the boundaries between the rights of an individual and the programmatic norms are sometimes hardly discernible. On the one hand, the CT concluded that a careful review of a specific constitutional provision is required in each case to determine whether or not the beneficiaries of the actions taken by public authorities in the area of ESC-rights are also the subjects of the right to demand specific actions for their benefit; a careful review is also required to determine the legal form of those actions ${ }^{10}$. On the other hand, the CT case law also includes an opposite view (which, however, is not the dominant view), whereby ESC-rights may be violated by the public authorities and as such, they may be the basis for a constitutional complaint in the following three special situations: 1) whenever the legislator applied means that may not lead to the implementation of a constitutional goal; 2) whenever a statute restricts a citizen in such a manner that it violates the essence of law; 3) whenever the statutory legal regulation does not take account of the minimum right delineated by its essence ${ }^{11}$.

Furthermore, Article 81 of the Constitution of the Republic of Poland clearly restricts the ability to enforce in court some social rights set out in that provision, up to the limits specified by the legislation ${ }^{12}$. The

work and has no other means of support, shall have the right to social security, the scope of which shall be specified by statute".

${ }^{10}$ Judgment of the Constitutional Tribunal of 2 July 2002, Case No. U 7/01, OTK ZU 2002, no. 4 A, item 48 .

${ }^{11}$ Judgment of the Constitutional Tribunal of 14 May 2001, Case No. SK 1/00, OTK ZU 2001, no. 4, item 84.

${ }^{12}$ Article 81 reads that: "The rights specified in Article 65, paras. 4 and 5, Article 66, Article 69, Article 71 and Articles 74-76, may be asserted subject to limitations specified by statute". 
Constitutional Tribunal itself, when giving judgments on ESC-rights, is very reticent when it comes to the acceptability of questioning violation of ESC-rights other than those set out in Article 81, including in particular those concerning social issues. In that case, the CT is of the view that the evaluation of the purposefulness and accuracy of parliamentary decisions is beyond its competencies, which include constitutional review of solutions adopted by the legislator. The Constitutional Tribunal is of the opinion that it is the duty of Parliament to select the most accurate solutions (in social and economic terms) and the Parliament bears political responsibility for the manner in which it uses its lawmaking competencies. As a consequence, the Tribunal's evaluation are limited only to cases where the legislator has overstepped its regulatory freedoms in a manner that violates the Constitution ${ }^{13}$. Arguing with this view, it should be stated that the CT has ability to control the choice of means used for the implementation of a specific goal delineated by the constitutional programmatic norms and for resolving conflicts of goals arising from such norms.

The next feature that is characteristic of the constitutional perspective on ESC-rights is that the Constitution of the Republic of Poland left the normative content of those rights to be regulated by the ordinary legislator to a much greater extent than in the case of civil- and political rights. What is more, there is no uniform framework that the Constitution has set for their regulation. In that respect, the ESC-rights may be sub-divided into three groups: ${ }^{14}$ As for the first group ${ }^{15}$ the Constitution itself sets forth certain assumptions, directions or action strategies; however, there is no

${ }^{13}$ This view was first formulated in the CT ruling dated 20 November 1995, Case No.: K 23/95, OTK 1995, Vol. II, item 33, p. 121, and was repeated on numerous occasions thereafter. C.f. for example: CT judgment dated 11 December 2006, Case No. SK 15/06, OTK ZU 2006, No. 11A, item 170, para. 44; judgment dated 12 September 2000, Case No. K 1/00, OTK ZU 2000, no. 6, item 185, para. 44; judgment dated 21 October 1998, Case No. K 24/98, OTK ZU 1998, no. 6, item 97, para. 62; judgment dated 27 January 2003, Case No. SK 27/02, OTK ZU 2003, no. 1A, item 2, para. 57.

${ }_{14}$ That distinction was made in the judgment of the Constitutional Tribunal of 2 July 2002, Case No. U 7/01, OTK ZU 2002, no. 4A, item 48.

15 Apart from Article 75.1, that group included the rights guaranteed under the following Articles of the Constitution: Article 65.5, Articles 68.3, 68.4 and 68.5, Article 69, Articles 72.1 and 72.2, Articles 74.1, 74.2 and 74.4, and Article 75.1. 
duty, in those regulations, to implement the tasks by enacting statutes. As for the second group, the ordinary legislator is obliged to make a statutory regulation without specifying in detail how that regulation should be made $^{16}$. In the case of the third group, there is not only the duty to enact a statute, but the subject matter or the direction of an ordinary statute are also defined to a certain extent ${ }^{17}$.

Last but not least, in the context of social rights, the Constitutional Tribunal is of the view that the duty imposed on the legislator to implement the welfare guarantees expressed in the Constitution is not a duty to expand the system of benefits as much as possible. By contrast, the duty must be understood as a duty to implement the content of constitutional law by statutory regulations in such a manner as to account for the existing needs on the one hand and to find ways to satisfy them on the other hand. In order to delineate the boundaries of those possibilities, it is necessary to account for other constitutional values that are subject to protection, such as budget equilibrium, which may, to a certain extent, be in opposition to the statutory solutions aimed at the maximization of the social guarantees. This does not, however, change the fact that the statutory implementation of the constitutional social right may never be below the minimum set by the essence of a given right ${ }^{18}$.

The Tribunal's understanding of that minimum may be found in the judgment in case no. P 13/14, where the CT concluded that any increase or decrease in expenditures on the implementation of social rights must be in accordance with the rules set out by the Constitution. However, the statutes must guarantee benefits that correspond to at least the minimum which is described as securing the basic needs ${ }^{19}$.

${ }^{16}$ Apart from Articles 67.1 and 67.2, that group also included the rights set out under the following Articles of the Constitution: Article 66.1, Article 68.2, Article 69, Articles 71.2 and Article 76, second sentence.

17 This refers to the rights expressed in: Article 64.3, Article 65.1-4, Article 66.2, Article 70.1, Article 70.3, and Article 75.2.

${ }_{18}$ CT judgment dated 8 May 2000, Case No. SK 22/99, OTK ZU 2000, no. 4, item 107, para. 39 of the judgment.

${ }^{19}$ CT judgment dated 24 October 2005, Case No. P 13/04, OTK ZU 2005, no. 9A, item 102 , para. 71 and the case law cited therein. 


\section{SUBSISTENCE MINIMUM GUARANTEED UNDER THE CONSTITUTION AS AN INHERENT CONSTITUTIONAL VALUE}

Unlike the ECS-rights, violation of civil- and political rights and freedoms may be questioned before the Constitutional Tribunal and the common courts of law without any limitations. The individual dignity guaranteed under Article 30 of the Constitution has a special meaning in the Polish legal system and is considered to be a source of rights and freedoms and a fundamental right.

The importance of human dignity was best characterized in the Constitutional Tribunal judgment given in case no. K 11/00, where the CT ruled on the constitutionality of the lack of legal guarantees protecting people living in poverty against eviction onto the streets. The Commissioner for Human Rights who initiated the proceedings before the Constitutional Tribunal, argued that such a legal regulation violates, among other things, Article 30 of the Constitution, which reads that "The inherent and inalienable dignity of the person shall constitute a source of freedoms and rights of persons and citizens. It shall be inviolable. The respect and protection thereof shall be the obligation of public authorities".

While deciding on the incompliance of the regulations with the Constitution, the CT concluded that the constitutional lawmaker made human dignity a constitutional concept and made it a reference point for a system of values on which the Constitution evolved, and the foundation of the entire legal system in the state. As noted by the CT, dignity must not be understood as a feature or a set of rights assigned by the state. That is because it has a primary position in relation to the state; hence, both the legislator and the authorities applying the law must respect the meaning of the term of dignity to which every human being is entitled ${ }^{20}$.

Furthermore, the Tribunal concluded that the ban on violating human dignity as defined in Article 30 is absolute and applicable to everyone. The duty to respect and protect dignity was imposed on the public authorities of the state; as a consequence, all actions of the public authorities should,

${ }^{20}$ CT judgment dated 4 April 2001, Case No. K 11/00, OTK ZU 2001, no. 3, item 54, para. 57. 
on the one hand, account for the existence of a certain autonomy zone within which a person may fully realize their social potential, and on the other hand those actions may not lead to creating legal or actual situations that deprive an individual of their sense of dignity ${ }^{21}$.

In the context of the public authorities' duty to respect and protect dignity, the CT concluded that "a premise for respecting [...] human dignity includes, among other things, the existence of a certain material minimum that provides the individual with the ability to function in the society on their own and to create opportunities for each person to fully develop their personality within their cultural- and civilizational surroundings" 22 .

This is how the CT noted the subsistence minimum guaranteed under the Constitution as an inherent constitutional value for the very first time in its history: the duty to ensure such subsistence minimum derives from human dignity. For a long time this had been the only judgment in which the Tribunal explicitly referred to that constitutional category.

This category was mentioned for the second time (and the last one so far) in the constitutional court decision in 2015 on the so called tax-free personal allowance, ${ }^{23}$ and was of key importance for the evaluation of the constitutionality of the regulation subject to review by the CT. This judgment is also important because of the fact that it is one of the very few rulings where the CT explicitly took efforts to protect individuals against sliding into poverty as a result of the actions of parliament.

The provision of the Personal Income Tax Act of 26 July 1991 that was subject of constitutional review in this case, established an amount of tax reduction for poor people at too low a level, which resulted in the fact that poor people, through the need to pay taxes on low earnings, become even poorer. In judgment $\mathrm{CT}$ concluded that such provision was incompliant with Articles 2 and 84 of the Constitution of the Republic of Poland insofar as it did not envisage a mechanism for adjusting the amount by which the tax is decreased that would at least guarantee the

${ }^{21}$ CT judgment dated 4 April 2001, Case No. K 11/00, OTK ZU 2001, no. 3, item 54, para. 59 of the judgment.

${ }^{22}$ CT judgment dated 4 April 2001, Case No. K 11/00, para. 60 of the judgment.

${ }_{23}$ CT judgment dated 28 October 2015, Case No. K 21/14, OTK ZU 2015, no. 9A, item 152. 
subsistence minimum ${ }^{24}$. Those two articles, mentioned above, define, respectively, the principle of social justice and the duty to incur a public burden, including taxes.

The fact that the petitioner in the case, that is the Commissioner for Human Rights (hereinafter: $\mathrm{CHR}$ ), did not raise in the plea violation of Article 30 of the Constitution was not an obstacle for the CT to use the subsistence minimum as the basis for its judgment. The Tribunal referred to that value and showed, in a very general manner, that there is a relation between the principle of social justice and protection of dignity.

As a result of that action, the CT was able to conclude that the said provision was unconstitutional because of the fact that the ability to pay taxes was not correlated with the regulations referring to the subsistence minimum or to other specific social and economic ratios. According to the Constitutional Court, "owing to the lack of such correlation, the regulations become unfair, even though they are correct in formal terms ${ }^{\prime 25}$. The Tribunal concluded that the legislator's duty to shape the tax rates in such a way as to prevent individuals from sliding into poverty derived from human dignity; ${ }^{26}$ furthermore, the Tribunal observed that "while customizing the tax liability, the Legislator must consider ensuring a subsistence minimum for individuals" 27 .

As for the second charge relating to the compliance of that provision with the duty to bear public burdens, including taxes, as set out in Article 84 of the Constitution, the Tribunal shared the view of the CHR who combined the duty to pay taxes with the ability to pay them, and argued that: if the country's system relies on the social market economy (Article 20 of the Constitution), then both the economic and market component and the social component must be taken into account when developing fiscal law. That means that the tax burden should not be greater than absolutely necessary. It should take account of the tax payers' individual

${ }^{24}$ Article 2: "The Republic of Poland shall be a democratic state ruled by law and implementing the principles of social justice".

Article 84: "Everyone shall comply with his responsibilities and public duties, including the payment of taxes, as specified by statute".

${ }^{25}$ CT judgment dated 28 October 2015, Case No. K 21/14, para. 227 of the judgment.

${ }^{26}$ CT judgment dated 28 October 2015, Case No. K 21/14, para. 214 of the judgment.

${ }^{27}$ CT judgment dated 28 October 2015, Case No. K 21/14, para. 214 of the judgment. 
ability to bear public burdens. The duty to pay taxes must not lead to the poverty of the citizens (tax payers).$^{28}$ Furthermore, the CT concluded that the "regulation which was the subject of the complaint is irrational in the case of individuals whose income is under the poverty line. This leads to expanding the poverty lines and making those people more dependent on the welfare system" 29 .

Those judgments are the basis for further development of the Constitutional Tribunal's case law concerning the subsistence minimum as an inherent constitutional value. It needs to be observed that in those rulings the Tribunal used the construct of the subsistence minimum in a negative context as a shield protecting an individual against the state, and in a positive context by creating the possibility for an individual to demand that the state take positive actions in order to guarantee that the individual's basic needs are met.

\section{4. "ThE FUndAMENTAL RIGHT TO GUARANTEE ASUBSISTENCE MINIMUM THAT IS IN LINE WITH HUMAN DIGNITY" IN THE JURISPRUDENCE of the German Federal Constitutional Court}

When passing its judgment on the tax-free personal allowance, the Polish $\mathrm{CT}^{30}$, was certainly inspired (as was explicitly mentioned in the reasoning) by the judgments of the Federal Constitutional Court of Germany (hereinafter: FCC) which inferred, from the human dignity principle protected under Article 1 of the Basic Law for the Federal Republic of Germany (ger. Das Grundgesetz für die Bundesrepublik Deutschland), in conjunction with the principle of the social welfare state guaranteed under Article 20, that there is The fundamental right to guarantee a subsistence minimum that is in line with human dignity (ger: "Das Grundrecht auf Gewährleistung eines menschenwürdigen Existenzminimums").

${ }^{28}$ CT judgment dated 28 October 2015, Case No. K 21/14, para. 223 of the judgment.

${ }^{29}$ CT judgment dated 28 October 2015, Case No. K 21/14, para. 228 of the judgment.

${ }^{30}$ CT judgment dated 28 October 2015, Case No. K 21/14, paras. 176-184 of the judgment. 
The judgments of the FCC referring to the relations between the fiscal burden and the right to subsistence minimum that guarantees dignity, which was referred to by the Polish Constitutional Tribunal in its reasoning, did not, however, expand on the duty to guarantee a subsistence minimum that is in line with human dignity. The FCC referred to that duty in a negative context, i.e. it defined the boundaries of the state's interference ${ }^{31}$.

Two FCC judgments are of key importance in order to understand the substance of the right to a subsistence minimum that is in line with human dignity. Those judgments are referred to as: Hartz IV ${ }^{32}$ dated 9 February 2010 and the judgment on the cash benefits for asylum seekers ${ }^{33}$ dated 18 July 2012. In those judgments, the FCC evaluated the legislation awarding specific benefits from the state budget with the fundamental right to the subsistence minimum that is in line with human dignity, which was derived from the Basic Law for the Federal Republic of Germany. When passing a judgment in those cases, the FCC had to refer to the positive side of that right, unlike with the tax cases. In this context, it is worth noting that the FCC's understanding of the right to the subsistence minimum relies on two assumptions. The first one is the recognition that the state is required to provide an individual with the minimum funds that allow the individual to exist whenever it is required for the dignified existence of the individual. The second assumption is the recognition

${ }^{31}$ See for example: The judgment of the German Federal Constitutional Court dated 29 May 1990, Case No. 1 BvL 20/84, 1 BVL 26/84,1 BVL4/86. For an overview of jurisprudence of FCC concerning the state's obligation to provide for minimum living conditions in the field of tax law see: T. Aubel, Das Gewährleistungsrecht auf ein menschenwürdiges Existenzminimum, "Linien der Rechtsprechung des Bundesverfassungsgerichts - erörtert von den wissenschaftlichen Mitarbeitern" 2011 (Band 2), p. 273-298.

32 The judgment of the German Federal Constitutional Court dated 9 February 2010, Case No. 1 BvL 1/09, 1 BvL 3/09, 1 BvL 4/09. The judgment is available on the website of the German Federal Constitutional Court in German and in English: http:/ / www.bundesverfassungsgericht.de/SharedDocs/Entscheidungen/EN/2010/02/1s201 00209_1bvl000109en.html (accessed on: 14.09.2018).

${ }^{33}$ The judgment of the German Federal Constitutional Court dated 18 July 2012, Case No. 1 BvL 10/10, 1 BvL 2/11. The judgment is available on the website of the German Federal Constitutional Court in German and in English: https:/ / www.bundesverfassungsgericht. de/SharedDocs/Entscheidungen/EN/2012/07/1s20120718_1bvl001010en.html (accessed on: 14.09.2018). 
that the duty is of a legal nature and the individual should have a right to claim that minimum ${ }^{34}$.

Those judgments, as is emphasized in the German legal doctrine, move away from the restrictive interpretation of social rights practiced so far, where asserting rights in court was considerably limited to progressive interpretation of the social state clause which paved way to enforcing such rights in court ${ }^{35}$. In this context it is worth underlining that the German Constitution, unlike the Polish Constitution, does not include a catalogue of ESC-Rights. The two basic reason for the lack of a comprehensive ESC-Rights catalogue in the German Constitution are as follows: firstly, the founding fathers of the Basic Law intended to make the text of the constitution strict and unconditional, so that it could abide unconditionally. Owing to the fact that ESC-Rights leaves wide room for interpretation and depends also on legislative implementation, the potential adoption of the ESC-Rights catalogue makes it impossible to reach that goal. Secondly, the Basic Law was intended originally to establish a legal regime for a short period of time, up to the unification of East and West Germany. Because of that the founding fathers intentionally abstained from providing a comprehensive catalogue of ESC-Rights so as to not anticipate a social order for unified Germany ${ }^{36}$.

The above-mentioned judgments can be seen also in a wider perspective, which includes an understanding of the notion of human dignity in German constitutional law. In this context it should be stated that dignity is seen by a majority opinion of German jurists, as well as in the jurisprudence of FCC, as an operative human right that can be invoked by individuals as well as an objective norm which directly binds all state authority. It should be also noted that FCC ruled on the matter

${ }^{34}$ C. Bittner, Case note - Human Dignity as a Matter of Legislative Consistency in an Ideal World: The Fundamental Right to Guarantee a Subsistence Minimum in the German Federal Constitutional Court's Judgment of 9 February 2010, “German Law Journal Review of Developments in German, European and International Jurisprudence" 2011, vol. 12, no. 11, p. 1943.

35 I.T. Winkler, C. Mahler, Interpreting the Right to a Dignified Minimum Existence: A New Era in German Socio-Economic Rights Jurisprudence?, "Human Rights Law Review" 2013, vol. 13, no. 2, p. 389.

${ }^{36}$ E. Eichenhofer, Social Rights in Germany [w:] K. Wojtyczek, (eds.) Social Rights as Fundamental Rights XIXth International Congress of Comparative Law, Hague, 2016, p. 160-162. 
of dignity on many occasions making dignity jurisprudence very wide and sophisticated ${ }^{37}$. In this context the above-mentioned judgments can also be seen as an obvious consequence of dignity case law stemming from the 60 s and 70 s.

\subsection{HARTZ IV JUDGMENT}

In Hartz IV, the FCC stated that the constitutional right to the subsistence minimum in line with dignity derived from the human dignity principle protected under Article 1 of the German Constitution, in conjunction with the principle of the social welfare state contained in Article 20 which ensures for each person in need of assistance the material prerequisites which are indispensable for his or her physical existence and for a minimum of participation in social, cultural and political life $\mathrm{e}^{38}$.

In that ruling, the FCC specified that the right to a subsistence minimum in line with dignity took on an autonomous significance. It is the legislator's role to give a specific shape to that right. The legislator does not have full freedom to act in that respect. He has, among other things, to adjust the levels of benefits that allow for the implementation of that right to the level of a country's development and the standards of living. While doing so, the legislator may consider typical human needs that must be met to ensure a subsistence minimum that is in line with dignity by means of a fixed monthly benefit, but at the same time the legislator has to award additional benefits to secure special needs that are not of a permanent nature. ${ }^{39}$

Three courts whose petitions started the constitutional review in that matter questioned the amount of the benefits paid out to people in need based on the Second book of the Social Law Code (German: Sozialgesetzbuch Zweites Buch SGB II), because they found the benefit amounts to be insufficient, and - by extension - unconstitutional. Apart from the benefit amount, there were also concerns about the constitutionality owing to

37 See more: H. Dreier [in:] H. Dreier (eds.) Grundgesetz Kommentar: GG Band I: Präambel,Artikel 1-19, Mohr Siebeck 2013, pp. 42-329; K. Stern, Das Staatsrecht der Bundesrepublik Deutschland Band IV/1: Die einzelnen Grundrechte, München 2006, pp. 60-73.

38 Judgment in Hartz $I V$, thesis 1.

39 Judgment in Hartz IV, theses 2-4. 
the fact that the benefit amount was not made dependent on whether the beneficiary had previously worked or not, which - in the petitioners' opinion - was to lead to a violation of the equality principle.

While passing judgment in that case, the Federal Constitutional Court did not decide whether or not the said benefit was too low and, as such, violated the Constitution. Such a conclusion would not be possible owing to the fact that, while the right to the subsistence minimum in line with dignity does derive from the Basic Law, the FCC is of the view that the Basic Law does not define the right to a benefit in a specific amount. The benefit amount should therefore be determined at the statutory level on the basis of an adequate and transparent procedure that takes account of the level of needs that need to be secured and the actual conditions in which the state operates, including in particular the degree of the social- and economic development of the state. In the view of the FCC, the legislator has a certain freedom to shape the benefits for individuals in need and the claims correlated with them. Because the Basic Law does not define the right to a benefit of a specific amount in a tangible manner, the material evaluation of FCC is limited only to obvious cases where the benefits were determined in an inadequate manner or if their amount is insufficient. ${ }^{40}$

While analyzing that specific case from a material point of view, FCC limited itself to stating that the benefit amount was not clearly insufficient. Thus, the constitutional court focused on examining the procedure for determining the benefit amount.

Then, the Tribunal determined the criteria that need to be applied to evaluate whether or not the legislation concerning the subsistence minimum was in line with the Basic Law from the procedural perspective ${ }^{41}$ :

1) Firstly, whether the legislature has covered and described the goal to ensure an existence that is in line with human dignity in a manner doing justice to Article 1.1 in conjunction with Article 20.1 of the Basic Law;

2) Secondly, whether within its margin of appreciation it has selected a calculation procedure that is fundamentally suited to an assessment of the subsistence minimum;

\footnotetext{
${ }^{40}$ Judgment in Hartz IV, para. 141.

${ }^{41}$ Judgment in Hartz IV, para. 143.
} 
3) Thirdly, whether, in essence, it has completely and correctly ascertained the necessary facts and, finally;

4) Fourthly, whether it has kept within the bounds of what is justifiable in all calculation steps with a comprehensible set of figures within this selected procedure and its structural principles.

While analyzing the provisions questioned in Hartz IV, FCC came to the conclusion that they did not meet all the requirements set out above.

Most significantly, while analyzing the statistical model that was the basis for the benefit calculation, the FCC found that the legislator did not present a justification for that choice ${ }^{42}$. The lack of a provision in the Hartz IV legislation that would be the basis for a claim for a benefit indispensable to meet the special needs that are not of one-off nature and that are necessary in order to guarantee the subsistence minimum in line with dignity, was found to be in breach with the constitutional right to the subsistence minimum in line with dignity ${ }^{43}$.

\subsection{JUDGMENT ON THE CASH BENEFITS FOR ASYLUM SEEKERS}

In the second case which is important for the understanding of the fundamental right to guarantee a subsistence minimum that is in line with human dignity, the FCC was to decide whether or not the German Asylum Seekers Benefits Act (German: Asylbewerberleistungsgesetz - AsylbLG) was in compliance with the Constitution. In that ruling, the FCC referred to the right to a subsistence minimum in line with dignity and expanded it so that it also covered individuals who were not German citizens.

During the FCC proceedings, the petitioner questioned the amount of the cash benefits because its amount had not been changed ever since the statute had been enacted. The court that initiated the proceedings before the FCC argued that the regulation was not compliant with the fundamental right to the subsistence minimum in line with dignity because the benefit amount was insufficient.

While evaluating the constitutionality of the aforementioned statute, the Federal Constitutional Court used, as a model, the right to the subsistence minimum in line with dignity and the criteria for the evaluation

\footnotetext{
${ }^{42}$ Judgment in Hartz IV, para. 173.

43 Judgment in Hartz IV, para. 204.
} 
of its violation that were worked out in Hartz IV. To declare the unconstitutionality of the provision, it was enough to apply the first criterion, that is to declare that the said benefit was evidently insufficient because its amount was set in 1993 and had not been changed ever since, while the prices in Germany had changed and had gone up by more than $30 \%$.

While justifying its decision, the FCC mentioned, among other thigs, that both German and foreign nationals who reside in Germany are entitled to the right to the subsistence minimum in line with dignity. Thus, benefits that implement that right must be determined based on the circumstances in Germany. While defining the minimum that allows for dignified life, the Constitution does not permit defining it by referring to the existence level in a country of origin of the people in need, or by referring to the existence level in other countries ${ }^{44}$.

Furthermore, the FCC gave a reminder of the importance of the right to the subsistence minimum that guarantees dignity by pointing out that the Constitution allows for compromise and political negotiations, and allows the legislature itself to select the method of ascertaining the basic human needs and the legislator's response thereto. However, if different methods are applied to different specific groups of individuals, this must be justifiable by facts. The benefits amount should also be subject to a periodic review, and raised, as appropriate, if the level of needs increased. According to the above considerations, differentiating the amount of benefits for persons with a temporary right of residence in Germany and persons with a permanent right of residence in a constitutional manner is possible. However, such a possibility exists only if the needs are actually lower. In order to take advantage of that possibility, the legislator must clearly indicate a group of persons who have resided in Germany for a shorter period of time and who may receive benefits in a lower amount. The refugee status may be a kind of guidance in that respect, but may not in itself justify a reduction of the benefit level. However, if an individual resides in Germany for a longer term, that special justification for a reduction of benefits becomes meaningless ${ }^{45}$.

As previously mentioned, the FCC stated that the basic benefit for foreigners was evidently insufficient. While the conclusion was sufficient

\footnotetext{
${ }^{44}$ Judgment in Hartz IV, para. 69.

45 Judgment in Hartz IV, paras. 72-78.
} 
to determine its unconstitutionality, the FCC also analyzed the legislation by indicating the criteria referred to in Hartz IV in order to reinforce the thesis that the regulation was not compatible with the Constitution.

The FCC stated, among other things, that the scope of the act was initially limited to individuals whose residence in Germany was expected to be brief. The scope of the Act had been extended several times, and at the time of the ruling it encompassed people with a highly diverse residential status, the majority of whom had been in Germany for more than six years. However, even a short period of residence or only shortterm prospects for residence in Germany would not justify, under the Constitution, a restriction of the claim to a guarantee of a dignified minimum existence as to physical needs alone. Those benefits should also include other social and economic needs. What is more, the said subsistence minimum in line with dignity must be guaranteed from the very beginning of an individual's stay in Germany ${ }^{46}$.

The Federal Constitutional Court also concluded that migrationpolicy considerations to keep benefits for asylum seekers and refugees low in order to discourage them from migration may generally not justify any reduction of benefits below the physical and sociocultural minimum existence that allows for preserving dignity. Human dignity may not be modified in light of migration-policy considerations ${ }^{47}$.

\section{IS IT POSSIBLE THAT THE POLISH CONSTITUtional TRIBUNAL INFERS THE INHERENT RIGHT TO THE SUBSISTENCE MINIMUM FROM THE CONSTITUTION?}

Some Polish constitutional law researchers see the need for inferring, from the Constitution, the right to protection from social exclusion ${ }^{48}$. However,

${ }^{46}$ Judgment in Hartz IV, para. 96.

47 Judgment in Hartz IV, para. 97.

${ }^{48}$ See: P. Tuleja, Prawa jednostki do ochrony przed wykluczeniem a konstytucyjne zadania państwa [The rights of individuals to be protected against exclusion and the constitutional tasks of state] [in:] Z. Kędzia, A. Rost (eds.), Wspótczesne wyzwania wobec praw człowieka w świetle polskiego prawa konstytucyjnego [Contemporary challenges of human rights in the light of Polish constitutional law], Poznań 2009, p. 147-161. 
bearing in mind the above cited judgments of the CT concerning social rights, further development of the case law concerning the subsistence minimum as a constitutional value (or perhaps a right in the future) seems much more likely. Defining that constitutional category as a right would be advantageous because the subsistence minimum could be used as a model for the constitutional review ${ }^{49}$.

So far, when speaking on the subject of the subsistence minimum, the Constitutional Tribunal did not follow its German counterpart and describe that value as a constitutional right; instead, the Polish Constitutional Tribunal only described it as a "constitutional value", even though it did have normative material that would allow it to reconstruct the constitutional right to the subsistence minimum comparable to the German one. The Federal Constitutional Court of Germany found that right in two provisions, notably in Article 1 of the German Constitution that guarantees respect of and protection for human dignity and in Article 20 of the German Constitution that describes Germany as a social welfare state. The Polish Constitution guarantees both human dignity (in Article 30) and the social welfare state principle as an element of the social market economy (Article 20).

The reasons behind that reticence include in particular the fact that the considerations regarding subsistence minimum were only an element of arguments in the first judgment that mentioned that value and it seems that they only served to settle that concept in the Polish normative order $^{50}$. There are at least two other reasons that the CT considered in its judgment concerning the tax-free personal allowance ${ }^{51}$ where that value was central to the Tribunal's attention.

${ }^{49}$ See Article 79.1 of the Polish Constitution which reads as follows: "In accordance with principles specified by statute, everyone whose constitutional freedoms or rights have been infringed, shall have the right to appeal to the Constitutional Tribunal for its judgment on the conformity to the Constitution of a statute or another normative act upon which basis a court or organ of public administration has made a final decision on his freedoms or rights or on his obligations specified in the Constitution."

${ }^{50}$ CT judgments: dated 15 November 2005, Case No. P 3/05, OTK ZU 2005, no. 10A, item 115; dated 4 April 2001, Case No. K 11/00, OTK ZU 2001, no. 3, item 54.

51 That is in the CT judgment dated 28 October 2015, Case No. K 21/14, OTK ZU 2015, no. 9A, item 152. 
First of all, there were 5 judges of the Tribunal adjudicating that matter, and according to the statute effective at the time when the decision was taken, in order to infer a new constitutional right from the Constitution, the matter should be reviewed by all judges because of its significance $^{52}$. That requirement was abolished by the currently effective statute..$^{53}$ This means that a 5-judge panel of the Constitutional Tribunal may infer the new right from the text of the Constitution.

Secondly, the petitioner - The Commissioner for Human Rights omitted Article 30 among the norms for the review which is indispensable for reconstructing such a right, and which is also of key importance for the protection of rights of individuals who live in extreme poverty ${ }^{54}$. The Tribunal gives human dignity central meaning in the entire system of constitutional axiology. In that context, a reference to Article 30 of the Constitution is always valid because the subject of the evaluation is the legal protection relating to the respect for the most vital interests of each individual, including those that relate to life, health, and physical integrity ${ }^{55}$. What is more, the right to the living minimum which is derived from the Constitution, using Article 30, would automatically mean that the right is found to be a fundamental right; as a consequence, in line with the CT judicial decisions, the legislator may not, as a matter of principle, question or restrict such a right because the substance of the rights derived from dignity is not dependent on the will of parliament, and even less dependent on the will of public authorities that apply that

52 Pursuant to Article 44.1.f) of the Constitutional Tribunal Act of 25 June 2015 (Journal of Laws of 2015, item 1064), which was effective when the decision in case no. K 21/14 was taken, the Tribunal shall sit in full court in matters that are of particular complexity or significance.

${ }^{53}$ C.f. Article 37 of the Organization and Procedure for Proceedings before the Constitutional Tribunal Act of 30 November 2016 (Journal of Laws, item 2072).

${ }^{54}$ While pointing to a positive aspect of dignity, Granat stated that "it seems that the positive aspect (if any) of respect for and protection of dignity consist in determining that human rights (such as the rights to shelter or rights specifying other specific living standards serve to "securing" dignity rather than "ensuring" it. In this case, the function of the human rights is to secure human dignity against its breach." - M. Granat, Godność człowieka $z$ art. 30 Konstytucji RP jako wartość i norma prawna [Human dignity in Article 30 of the Polish Constitution as a value and legal norm], "Państwo i Prawo" 2014, vol. 8, p. 7.

${ }_{55}$ Judgment of the Constitutional Tribunal of 1 September 2006, Case No. U 14/05, OTK ZU 2006, no. 8A, item 97, para. 75 of the judgment. 
right $^{56}$. This is because of the fact that if the subject initiating proceedings before the constitutional court invokes Article 30 of the Constitution, the provision subject to the review by CT will not be evaluated only from the technical or procedural perspective.

Inferring a new constitutional right needs to be considered to be more important than merely deciding on whether or not a given provision is unconstitutional; in the case discussed herein, it was "enough" for the Tribunal to find a constitutional value of the subsistence minimum in the principle of social justice in conjunction with the principle of dignity. That measure was criticized by CT judge Stanisław Rymar, who accused the Tribunal, in his dissenting opinion, of relieving the petitioner of the duty to select the right arguments to support its concerns ${ }^{57}$.

The above thesis that it is possible to infer the right (rather than only a value) to subsistence minimum from the Constitution is additionally justified in the dissenting opinion of Judge S. Rymar. While the Tribunal used the term "constitutional value" when referring to the subsistence minimum in its judgment, Judge S. Rymar, in his dissenting opinion, took it a step further and wrote about the "constitutional right to the subsistence minimum", rather than describing it as a "value". We can only hope that the use of such a phrase is a predictor of the direction in which constitutional case law will evolve.

However, it is also possible that the process of evolution of CT case law described above will never occur because of the constitutional crisis that has existed in Poland since 2015. The CT in Poland has not been operating properly ever since that time. The ruling party paralyzed it first by electing new judges to the Constitutional Tribunal for three places which were not vacant (they were occupied by judges elected by the previous Parliament). The Constitutional Tribunal itself ruled that

${ }^{56}$ CT judgment dated 15 November 2000, Case No. P 12/99, OTK ZU 2000, no. 7, item 260, para. 36 of the judgment.

57 The critique of Judge S. Rymar also concerned other elements of the Tribunal's reasoning, including in particular the CT's opinion that the regulation subject to review was incompliant with the Constitution because it failed to correlate the ability to pay taxes with the regulations referring to the subsistence minimum or to other specific social and economic ratios. Judge Rymar found that the Tribunal failed to demonstrate noncompliance of the norms in terms of hierarchy and only described a potential inconsistency between norms having the same legal effect. 
those three new judges were not in fact judges. Ultimately, however, the faux judges were admitted to act as judges by the politically appointed new president of the Constitutional Tribunal. The three real judges had not been admitted to the Constitutional Tribunal because the President refused to accept their oath. Since November 2015, the Parliament has adopted many legal acts amending the Act on the Constitutional Court, which were aimed at paralyzing the Tribunal's work. At present, most of the judges (including the three faux judges) of the Constitutional Tribunal are connected with the ruling party and the Tribunal has ceased to fulfill its role. On the rare occasions that it does actually proceed with a case regarding the constitutionality of a given law, the Court does not provide any judgment in opposition to government opinions ${ }^{58}$.

On the other hand the further development of CT case-law in terms of subsistence minimum cannot be excluded owing to the fact that the rights of people living in poverty are not the subject of a political dispute. What is more, the Constitutional Tribunal can legitimize its existence through the development of case law in this area.

\section{CONCLUSION}

Because of the restrictions in the constitutional law of many countries as to the possibility of questioning violations of ESC-rights, guarantees that derive from the rights and freedoms of the first generation and general

58 See more: P. Radziewicz, P. Tuleja (red.) Konstytucyjny spór o granice zmian organizacji i zasad działania Trybunału Konstytucyjnego: czerwiec 2015-marzec 2016 [Constitutional dispute about the limits of changes in organization and principles governing the activities of the Constitutional Tribunal: June 2015-March 2016], Warszawa 2017; K. Łakomiec (red.) Funkcjonowanie Trybunatu Konstytucyjnego w latach 2014-2017 [Functioning of the Constitutional Tribunal between 2014 and 2017], Fundacja Batorego, Warszawa, 2018 M. Matczak, Poland's Constitutional Tribunal under PiS control descends into legal chaos, VerfBlog,2017/1/11; and more generally: W. Sadurski, How Democracy Dies (in Poland): A Case Study of Anti-Constitutional Populist Backsliding [in] Sydney Law School Research Paper No. 18/01; M. Wyrzykowski, "Wrogie przejęcie” porządku konstytucyjnego ['Hostile takover' of the constitutional order] [in:] M. Bernatt and others (eds.) "Wyzwania dla ochrony konkurencji i regulacji rynku. Księga jubileuszowa dedykowana profesorowi Tadeuszowi Skocznemu" [Challenges for the protection of competition and market regulation. Esseys in honour of Professor Tadeusz Skoczny], Warszawa 2017 r., s. 831-853. 
constitutional principles that define the system of specific countries become fundamental for the protection of the rights of individuals who live in extreme poverty. The judicial decision of the Federal Constitutional Court of Germany that derived "The fundamental right to guarantee a subsistence minimum that is in line with human dignity" from the German Basic Law is a special example of the potential that exists in those regulations. The Polish Constitutional Tribunal followed in its footsteps when it decided that the duty of public authorities to ensure subsistence minimum derived from dignity guaranteed under the Constitution; however, it did not describe it as an inherent right guaranteed to each and every individual.

Nevertheless, the judicial decisions of the Federal Constitutional Court of Germany concerning the right to subsistence minimum to which the Polish Constitutional Tribunal referred in its judgment, are not a unique phenomenon in the world. That right was also inferred by the constitutional courts from the constitutions of Switzerland and Columbia.

In Switzerland, the Federal Court found in its judgment dated 27 October $1995^{59}$ that the Swiss Constitution contained, implicitly, the right to secure existence (German: ein Grundrecht auf Existenzsicherung, French: Droit à des conditions minimales d'existence) which consisted in providing individuals with basic needs, such as food, clothing, and shelter which are an indispensable condition for their existence and development, and which are an indispensable element of a lawful and democratic state $^{60}$. In its reasoning for inferring that right from the Constitution, the Swiss Federal Court pointed to the consensus in the legislation of the individual cantons that guarantee assistance to individuals in ensuring their existence and in the legal doctrine, while on the other hand the Court pointed to the correlation between that right and other constitutional values expressed explicitly in the Basic Law. Most significantly, the Swiss Federal Court pointed to: the right to live, personal freedom, and the right

59 Judgment of the Federal Court of the Swiss Confederation dated 27 October 1995, in V.v. Einwohnergemeinde X. und Regierungsrat des Kantons Bern, case file no. BGE/ATF 121 I 367. The judgment in German is available on the Tribunal's website at: http:/ / relevancy. bger.ch/php/clir/http/index.php?lang=de\&zoom=\&type=show_document\&highlight_ docid $=$ atf $\% 3 A \% 2 F \% 2 F 121-I-367 \% 3 A d e$ (accessed on: 29.09.2018).

${ }^{60}$ Judgment in V. v. Einwohnergemeinde X. und Regierungsrat des Kantons Bern, p. 371. 
to decide for oneself - those rights may not be exercised if the individual is not provided with the ability to implement basic needs that allow him or her to to exist. Similarly to the constitutional courts in Poland and Germany, the Swiss Federal Court also pointed to the special importance of human dignity owing to which individuals may expect help simply because they are human beings, and to the principle of equality which is to ensure the minimum level of material justice ${ }^{61}$.

The Constitutional Court of Columbia also inferred the right of every person to minimum conditions for a dignified life (Spanish: minimo vital) from the Columbian Constitution. In this case, the Court found human dignity and four rights expressed in the Constitution, which is the right to life, the right to health, the right to work, and the right to social security, to be of fundamental importance for its ruling ${ }^{62}$.

${ }^{61}$ Judgment in V. v. Einwohnergemeinde X. und Regierungsrat des Kantons Bern, p. 372.

${ }^{62}$ C.f. Columbian Constitutional Tribunal judgment dated 12 May 1995, Case No. T-207/95; c.f. CCT judgment dated 16 February 2011, Case No. T-581A/11. See more:

R. Arango, J. Lemaitre (eds.), Jurisprudencia Constitucional sobre el derecho al mínimo vital, Bogotá 2002; M. Sepúlveda, Colombia. The Constitutional Court's Role in Addressing Social Injustice, M. Langford (ed.), Social Rights Jurisprudence Emerging Trends in International and Comparative Law, Cambridge 2008; pp. 144-162. 